\section{Jatrophane Diterpenoids With Protective Effect on Human Lymphocytes DNA}

\author{
Gordana Krstić', Milka Jadranin ${ }^{2}$, Miroslava Stanković ${ }^{3}$, \\ Ivana Aljančić', Ljubodrag Vujisić', Boris Mandić', and Vele Tešević'
}

Natural Product Communications

May 2019: 1-7

(C) The Author(s) 2019

Article reuse guidelines:

sagepub.com/journals-permissions

DOI: 10.1 I $77 / 1934578 \times 19848168$

journals.sagepub.com/home/npx

\begin{abstract}
Two sets of structurally different jatrophanes (I-I I and I3-I6), jatrophane I 2, and latex extract of 2 Euphorbia species (I7 and 18) were tested for in vitro protective effect against chromosome aberrations in peripheral human lymphocytes using the cytokinesis-block micronucleus (CBMN) assay. Jatrophanes I-6 in minimal doses of I $\mu \mathrm{g} / \mathrm{mL}$ prominently decreased micronuclei (MN) frequency in the range $44.86 \%$ to $34.29 \%$ and manifested considerable protective effect. From the other set of jatrophanes, $\mathbf{I} \mathbf{3}$ in the same minimal dose notably decreased MN frequency by $31.05 \%$, while extracts $\mathbf{I 7}$ and $\mathbf{I 8}$ at a concentration of $4 \mu \mathrm{g} / \mathrm{mL}$ remarkably decreased the frequency of $M N$ by $37.94 \%$ and $36.12 \%$, respectively. Jatrophanes $\mathbf{I 2}$, I4, and 16 showed moderate protection, while $7-I I$ and I5 were less active than positive control. The structure-activity relationship (SAR) studies of the tested jatrophanes (I-I6) indicated the favorable position of benzoate at C-8 or C-9 (3, 4, and I3) and a preference of isobutanoyloxy group at C-3 (I-3) rather than propanoyloxy at the same position (4-6) for pronounced protective effect on human lymphocytes DNA. In a previous SAR study on II jatrophanes (I, 3-8, and I3-16), the same structural features in 3, 4, and I 3 influenced powerful inhibition of P-gP, while growth inhibition of cancer cells was more than doubled in I (isobutanoyloxy group at C-3) compared to 6 (propanoyloxy at C-3).
\end{abstract}

\title{
Keywords
}

CBMN assay, MN, human lymphocytes, jatrophanes, protective effect, SAR studies

Received: October 17th, 2018; Accepted: January 9th, 2019.

Some degenerative illnesses such as Alzheimer's and Parkinson's disease manifest in higher level of micronuclei $(\mathrm{MN})$ as products of chromosome breakage or loss in peripheral blood lymphocytes. ${ }^{1,2}$ The cytokinesis-block micronucleus (CBMN) assay, based on cytokinesis inhibition by cytochalasin B (Cyt-B), has facilitated MN analysis exclusively in binucleate (BN) cells that have completed their first in vitro division after treatment with the test agent or following culture initiation..$^{3-7}$ The CBMN assay in peripheral blood lymphocytes has been used to detect DNA and chromosome damage as a consequence of an autoimmune disease,${ }^{8}$ chronic kidney disease, ${ }^{9}$ type 2 diabetes, ${ }^{10}$ metabolic syndrome, ${ }^{11}$ head and neck cancer, ${ }^{12}$ and other illnesses, or to evaluate the presence and extent of chromosomal damage in human populations that are exposed to genotoxic agents. ${ }^{13}$

Natural phenolic compounds from medicinal herbs and dietary plants play an important role in cancer prevention and treatment. ${ }^{14} \mathrm{CBMN}$ assays have shown that treatment of human lymphocytes with natural phenolic compounds, such as flavonoids, ${ }^{15,16}$ diarylheptanoids, ${ }^{17,18}$ or seeds extracts from grape ${ }^{19}$ raspberry, blackberry, and currant, ${ }^{20-22}$ induced decrease in the frequency of micronuclei and manifested protective effect on human lymphocytes DNA, compared to the action of alkylating agent mitomycin $\mathrm{C}$ (MMC) (negative control) and/or amifostine WR-2721 (positive control).

Genus Euphorbia (family Euphorbiaceae) is a rich source of jatrophanes, macrocyclic diterpenoids with trans-bicyclo[10.3.0.]pentadecane structure characterized by a flexible 12 -membered ring. Jatrophanes may perform different biological activities such as cytotoxic, ${ }^{23}$ antimicrobial, ${ }^{24}$ antiviral, ${ }^{25,26}$ and lipid-lowering activity, ${ }^{27}$ or may modulate overexpression of P-glucoprotein (P-gp) in order to overcome multidrug resistance to anticancer drugs. ${ }^{28,29}$ Several jatrophanes exhibit microtubule (MT) interacting activity

\footnotetext{
'University of Belgrade, Faculty of Chemistry, Serbia

${ }^{2}$ Institute of Chemistry, Technology and Metallurgy, Center for Chemistry, University of Belgrade, Serbia

${ }^{3}$ Nuclear Facilities of Serbia,Vinča, Serbia

Corresponding Author:

Vele Tešević, University of Belgrade, Faculty of Chemistry, Studentski trg 12-16, III58 Belgrade, Serbia.

Email: vtesevic@chem.bg.ac.rs
} 
and induce paclitaxel-like microtubules. ${ }^{30,31}$ Compounds that stabilize MT represent potential therapeutic approach for the treatment of Alzheimer's disease and related tauopathies. $^{32}$

In this study 16 jatrophane diterpenoids isolated from Euphorbia dendroides ${ }^{33,34}$ and latex extracts from E. dendroides and Euphorbia nicaeensis induced decrease in the frequency of $\mathrm{MN}$ and manifested protective effect on human lymphocytes DNA.

Jatrophanes 1-16 and extracts of lyophilized latex of 2 Euphorbia species (17 and 18) were tested for in vitro protective effect against chromosome aberrations in peripheral human lymphocytes using cytochalasin-B blocked MN assay. The cell cultures were treated with amifostine WR-2721 (positive control) at a concentration of $1 \mu \mathrm{g} / \mathrm{mL}$ and gave a significant $(P<0.01)$ decrease in the MN frequency of $17.94 \%$ compared to control cell cultures. The treatment with alkylating agent MMC (negative control) at a concentration of $0.2 \mu \mathrm{g} / \mathrm{mL}$ gave a significant $(P<0.01)$ increase in the MN frequency of $36.46 \%$ compared to control cell cultures. After treatment of cell cultures with 1-18 at concentrations of $1.0,2.0$, and $4.0 \mu \mathrm{g} / \mathrm{mL}$, the frequencies and distribution of MN in human lymphocytes were scored and the results are presented in Table 1.

In the course of a structure-activity relationship (SAR) study, jatrophanes were classified into 2 groups. The first group (1-11) are penta- or hexaesters with a carbonyl at C-14, an endocyclic 11(12)E-double bond, and an exomethylene 6,17-double bond. Jatrophane 12 stands apart as a single triester with an additional carbonyl at C-9, otherwise with the same structural features as 1-11. The second group (13-16) are heptaesters that differ from $\mathbf{1}$ to $\mathbf{1 1}$ by an endocyclic-5,6-double bond, instead of an exomethylene 6,17-double bond in the latter (Figure 1). In the CBMN assay the increased concentration of applied jatrophane (from 1.0 to $4.0 \mu \mathrm{g} / \mathrm{mL}$ ) decreased the level of $\mathrm{MN}$ in human lymphocytes and consequently afforded better protection.

Jatrophanes 1-3 have shown the prominent protective effect in minimal concentration of $1 \mu \mathrm{g} / \mathrm{mL}$ decreasing the frequency of $\mathrm{MN}$ by $44.86 \%, 43.53 \%$, and $41.44 \%$, respectively, compared to control human lymphocytes (Table 1). In the same concentration jatrophanes 4-6 decreased frequency of MN by $36.11 \%, 34.43 \%$, and $34.29 \%$, respectively. The chemical structures of 1-6 are rather uniform and only differ in an ester group at $\mathrm{C}-3$ (either $\mathrm{OiBu}$ or $\mathrm{OPr}$ ) and at $\mathrm{C}-8$ position (OAc, $\mathrm{OBz}$, or ONic), while the rest of the molecular structure of 1-6 are equal to each other. Higher protection of human lymphocyte DNA was observed when isobutanoyloxy is at C-3, rather than propanoyloxy at the same position (comparison of $\mathbf{1}$ to $\mathbf{6}$ and $\mathbf{3}$ to $\mathbf{4}$ ).

Weaker protective effect but still higher than positive control was observed when the highest dose $(4 \mu \mathrm{g} / \mathrm{mL})$ of $\mathbf{7 ,}, \mathbf{8}$, and 12 was applied, to decrease MN frequency by $23.18 \%$, $21.09 \%$, and $22.66 \%$, respectively. In the same dose, jatrophanes 9-11 that structurally differ from $\mathbf{1}$ to $\mathbf{8}$ by
5-ONic (instead of OAc), 15-OAc (instead of $\mathrm{OH}$ ), and 3-OAc (instead of OiBu or OPr), respectively, produced lower results than positive control decreasing $\mathrm{MN}$ frequency by $17.18 \%, 16.80 \%$, and $8.42 \%$, respectively (Figure 1, Table 1). On the other hand much weaker protective effect of 8 (with isobutanoyloxy at C-3), compared to structurally almost identical $\mathbf{5}$ (propanoyloxy at C-3), cannot be explained.

Among the tested jatrophanes of the second group the most effective was $\mathbf{1 3}$ with benzoyloxy at C-9 that in minimal concentration of $1 \mu \mathrm{g} / \mathrm{mL}$ gave $31.05 \%$ decrease in frequency of $\mathrm{MN}$. Jatrophane 14 differing from 13 by a nicotinyloxy group at C-9, instead of benzoyloxy at the same position in the latter, decreased MN frequency by $20.31 \%$. Jatrophane 15 with propanoyloxy at C-3 contrary to acetate at C-3 in $\mathbf{1 4}$ decreased the frequency of MN by $10.10 \%$. In the same concentration 16 with nicotinyloxy at C-8, differing from 14 by an acetate at C-8, decreased MN frequency by $24.93 \%$, respectively.

The tested hexane extracts of lyophilized latex of $E$. dendroides (17) and E. nicaeensis (18) exhibited prominent effect decreasing the frequency of $\mathrm{MN}$ by $37.94 \%$ and $36.12 \%$, respectively, at a concentration of $4 \mu \mathrm{g} / \mathrm{mL}$ when compared to control human lymphocytes (Table 1).

Antioxidant potential of heterocyclic compounds using CBMN assay has been summarized in a review. ${ }^{35}$ Polyphenols could reduce the incidence of single-strand breaks in double-stranded DNA, as well as radical-induced base damage. ${ }^{36}$

MT stabilizing drugs may be utilized in treatment of neurodegenerative diseases to compensate for the loss of tau function and to maintain or restore effective axonal transport. Although a growing number of MT stabilizing natural products continue to be discovered, only a few selected compounds, such as paclitaxel and epothilone, have been characterized as potential candidates for the treatment of neurodegenerative diseases. ${ }^{32}$

Jatrophanes isolated from Euphorbia semiperfoliata Viv. stimulated purified tubulin assembly in vitro. The rearrangement of MT was in contrast to the bundling produced by paclitaxel. ${ }^{30}$ In another study, nontoxic jatrophane 6 that showed inhibitory effect on cancer cell was incubated with tubulin solution and MT assembly was examined. The $\mathrm{IC}_{50}$ value for 6 was $29 \mu \mathrm{M}$, compared to $0.7 \mu \mathrm{M}$ for paclitaxel. ${ }^{31}$ Despite their structural difference from paclitaxel and other MT-interacting agents, the potential of jatrophanes as MT stabilizing drugs has not been investigated thoroughly.

As revealed in a previous SAR study on P-gp inhibition of 11 jatrophanes $\left(\mathbf{1}, \mathbf{3 - 8}\right.$, and 13-16) in colorectal carcinoma, ${ }^{34}$ 3, 4, and 13 happen to be the most powerful inhibitors of P-gp. In a SAR study on protective effect against chromosome aberrations in peripheral human lymphocytes the larger number of jatrophanes (1-16) was examined. The most remarkable protection was obtained with jatrophanes 1-6 and $\mathbf{1 3}$ at a concentration of $1 \mu \mathrm{g} / \mathrm{mL}$. Both SAR studies of 
Table I. Incidence of MN, Distribution MN Per Cells, CBPI, and Frequency of MN Measurement in Cell Cultures of Human Lymphocytes Treated With Different Concentration of I-I8.

\begin{tabular}{|c|c|c|c|c|c|c|}
\hline $\begin{array}{l}\text { Tested compounds } \\
\text { and extracts }\end{array}$ & $\begin{array}{l}\text { Conc., } \mu g / \\
\mathrm{mL}\end{array}$ & $\mathrm{MN} / \mathrm{I} 000 \mathrm{Bn}$ cell & $\%$ Bn cell with $M N$ & MN/Bn Cell & CBPI & $\begin{array}{c}\text { Frequency of } \mathrm{MN} \\
(\%)\end{array}$ \\
\hline Control & & $27.62 \pm 0.55$ & $2.29 \pm 0.08$ & $1.21 \pm 0.03$ & $1.62 \pm 0.04$ & 100.00 \\
\hline Amifostine & 1.0 & $22.64 \pm 0.78^{\mathrm{a}}$ & $1.89 \pm 0.10$ & $1.23 \pm 0.06$ & $1.65 \pm 0.04$ & 82.06 \\
\hline MMC & 0.2 & $37.42 \pm 1.78^{\mathrm{a}, \mathrm{b}}$ & $3.26 \pm 0.15$ & $1.12 \pm 0.04$ & $1.76 \pm 0.08$ & 136.46 \\
\hline \multirow[t]{3}{*}{ I } & 1.0 & $14.74 \pm 1.21^{a, b, c}$ & $1.18 \pm 0.17$ & $1.28 \pm 0.09$ & $1.73 \pm 0.07$ & 55.14 \\
\hline & 2.0 & $14.03 \pm 1.26^{a, b, c}$ & $1.25 \pm 0.14$ & $1.12 \pm 0.03$ & $1.77 \pm 0.07$ & 52.49 \\
\hline & 4.0 & $13.69 \pm\left. 2.1\right|^{a, b, c}$ & $1.25 \pm 0.13$ & $1.08 \pm 0.06$ & $1.58 \pm 0.05$ & 51.21 \\
\hline \multirow[t]{3}{*}{2} & 1.0 & $16.08 \pm 0.57^{a, b, c}$ & $1.42 \pm 0.11$ & $1.21 \pm 0.07$ & $1.57 \pm 0.02$ & 56.47 \\
\hline & 2.0 & $\mathrm{I} 5.92 \pm 0.6 \mathrm{I}^{\mathrm{a}, \mathrm{b}, \mathrm{c}}$ & $1.29 \pm 0.08$ & $1.19 \pm 0.06$ & $1.58 \pm 0.03$ & 55.78 \\
\hline & 4.0 & $14.74 \pm 0.39^{a, b, c}$ & $1.31 \pm 0.08$ & $1.22 \pm 0.07$ & $1.63 \pm 0.04$ & 51.64 \\
\hline \multirow[t]{3}{*}{3} & 1.0 & $16.73 \pm 1.08^{a, b, c}$ & $1.41 \pm 0.11$ & $1.17 \pm 0.07$ & $1.66 \pm 0.09$ & 58.56 \\
\hline & 2.0 & $16.28 \pm|.3|^{\mathrm{a}, \mathrm{b}, \mathrm{c}}$ & $1.42 \pm 0.11$ & $1.18 \pm 0.06$ & $1.67 \pm 0.08$ & 57.21 \\
\hline & 4.0 & $15.64 \pm 1.02^{a, b, c}$ & $1.42 \pm 0.09$ & $1.13 \pm 0.02$ & $1.67 \pm 0.03$ & 54.67 \\
\hline \multirow[t]{3}{*}{4} & 1.0 & $18.19 \pm 0.72^{a, b, c}$ & $1.48 \pm 0.05$ & $1.12 \pm 0.05$ & $1.58 \pm 0.01$ & 63.89 \\
\hline & 2.0 & $17.72 \pm 0.59^{a, b, c}$ & $1.47 \pm 0.04$ & $1.18 \pm 0.03$ & $1.59 \pm 0.01$ & 62.13 \\
\hline & 4.0 & $16.78 \pm 0.87^{a, b, c}$ & $1.42 \pm 0.04$ & $1.17 \pm 0.06$ & $1.61 \pm 0.03$ & 58.89 \\
\hline \multirow[t]{3}{*}{5} & 1.0 & $\mathrm{I} 8.57 \pm 0.8 \mathrm{I}^{\mathrm{a}, \mathrm{b}, \mathrm{c}}$ & $1.59 \pm 0.09$ & $1.14 \pm 0.09$ & $1.61 \pm 0.02$ & 65.57 \\
\hline & 2.0 & $18.23 \pm 1.10^{a, b *, c}$ & $1.57 \pm 0.09$ & $1.18 \pm 0.08$ & $1.59 \pm 0.02$ & 63.89 \\
\hline & 4.0 & $17.07 \pm 1.29^{a, b, c}$ & $1.52 \pm 0.10$ & $1.21 \pm 0.09$ & $1.63 \pm 0.04$ & 60.02 \\
\hline \multirow[t]{3}{*}{6} & 1.0 & $17.57 \pm 1.12^{a, b^{*}, c}$ & $1.49 \pm 0.12$ & $1.19 \pm 0.06$ & $1.70 \pm 0.05$ & 65.71 \\
\hline & 2.0 & $16.21 \pm 1.67^{a, b^{*}, c}$ & $1.38 \pm 0.08$ & $1.17 \pm 0.06$ & $2.02 \pm 0.03$ & 60.64 \\
\hline & 4.0 & $15.56 \pm 0.84^{a, b, c}$ & $1.27 \pm 0.11$ & $1.23 \pm 0.05$ & $1.61 \pm 0.01$ & 58.21 \\
\hline \multirow[t]{3}{*}{7} & 1.0 & $23.71 \pm 0.26^{a, c}$ & $1.78 \pm 0.04$ & $1.31 \pm 0.03$ & $1.67 \pm 0.09$ & 83.21 \\
\hline & 2.0 & $23.33 \pm 0.74^{a, c}$ & $1.79 \pm 0.03$ & $1.34 \pm 0.05$ & $1.59 \pm 0.03$ & 81.78 \\
\hline & 4.0 & $21.92 \pm 0.65^{a, c}$ & $1.54 \pm 0.08$ & $1.41 \pm 0.02$ & $1.67 \pm 0.09$ & 76.82 \\
\hline \multirow[t]{3}{*}{8} & 1.0 & $24.44 \pm 0.68^{a, c}$ & $1.98 \pm 0.07$ & $1.31 \pm 0.06$ & $1.71 \pm 0.08$ & 85.64 \\
\hline & 2.0 & $24.01 \pm 0.67^{a, c}$ & $1.92 \pm 0.06$ & $1.34 \pm 0.06$ & $1.63 \pm 0.04$ & 84.25 \\
\hline & 4.0 & $22.49 \pm 0.39^{a, c}$ & $1.77 \pm 0.09$ & $1.22 \pm 0.05$ & $1.67 \pm 0.05$ & 78.91 \\
\hline \multirow[t]{3}{*}{9} & 1.0 & $24.99 \pm 0.82^{a^{*}, c}$ & $1.88 \pm 0.05$ & $1.28 \pm 0.02$ & $1.71 \pm 0.02$ & 87.67 \\
\hline & 2.0 & $24.51 \pm 0.56^{a, c}$ & $1.86 \pm 0.04$ & $1.27 \pm 0.03$ & $1.64 \pm 0.03$ & 86.04 \\
\hline & 4.0 & $23.57 \pm 0.62^{a, c}$ & $1.76 \pm 0.14$ & $1.28 \pm 0.04$ & $1.76 \pm 0.08$ & 82.82 \\
\hline \multirow[t]{3}{*}{10} & 1.0 & $24.60 \pm 0.86^{c}$ & $1.93 \pm 0.08$ & $1.28 \pm 0.04$ & $1.72 \pm 0.04$ & 92.03 \\
\hline & 2.0 & $23.75 \pm 0.39^{\mathrm{a}, \mathrm{c}}$ & $1.86 \pm 0.09$ & $1.23 \pm 0.05$ & $1.67 \pm 0.02$ & 88.85 \\
\hline & 4.0 & $22.24 \pm 0.63^{\mathrm{a}, \mathrm{c}}$ & $1.64 \pm 0.13$ & $1.32 \pm 0.11$ & $1.66 \pm 0.01$ & 83.20 \\
\hline \multirow[t]{3}{*}{ II } & 1.0 & $26.30 \pm 1.66^{c}$ & $2.17 \pm 0.14$ & $1.21 \pm 0.02$ & $1.66 \pm 0.06$ & 98.39 \\
\hline & 2.0 & $25.25 \pm 1.26^{\mathrm{c}}$ & $2.09 \pm 0.13$ & $1.14 \pm 0.04$ & $1.64 \pm 0.02$ & 94.46 \\
\hline & 4.0 & $24.48 \pm 0.8 I^{c}$ & $1.94 \pm 0.10$ & $1.21 \pm 0.03$ & $1.67 \pm 0.01$ & 91.58 \\
\hline \multirow[t]{3}{*}{12} & 1.0 & $22.37 \pm 0.42^{a, c}$ & $1.91 \pm 0.04$ & $1.13 \pm 0.03$ & $1.66 \pm 0.05$ & 78.62 \\
\hline & 2.0 & $22.04 \pm 0.48^{a, c}$ & $1.89 \pm 0.02$ & $1.18 \pm 0.03$ & $1.68 \pm 0.05$ & 77.18 \\
\hline & 4.0 & $20.93 \pm 0.89^{a, c}$ & $1.74 \pm 0.06$ & $1.14 \pm 0.06$ & $1.59 \pm 0.02$ & 77.34 \\
\hline \multirow[t]{3}{*}{13} & 1.0 & $18.43 \pm 0.46^{a, b, c}$ & $1.56 \pm 0.04$ & $1.14 \pm 0.05$ & $1.64 \pm 0.01$ & 68.95 \\
\hline & 2.0 & $17.69 \pm 0.83^{a, b, c}$ & $1.56 \pm 0,04$ & $1.08 \pm 0.02$ & $1.61 \pm 0.02$ & 66.18 \\
\hline & 4.0 & $16.40 \pm 1.59^{a, b *, c}$ & $1.34 \pm 0.17$ & $1.32 \pm 0.06$ & $1.62 \pm 0.02$ & 61.35 \\
\hline \multirow[t]{3}{*}{14} & 1.0 & $21.30 \pm 0.95^{a, c}$ & $1.71 \pm 0.12$ & $1.25 \pm 0.05$ & $1.71 \pm 0.05$ & 79.69 \\
\hline & 2.0 & $20.70 \pm 0.84^{a, c}$ & $1.68 \pm 0.05$ & $1.23 \pm 0.06$ & $1.68 \pm 0.06$ & 77.44 \\
\hline & 4.0 & $19.37 \pm 0.34^{a, b^{*}, c}$ & $1.66 \pm 0.04$ & $1.12 \pm 0.04$ & $1.65 \pm 0.01$ & 72.46 \\
\hline
\end{tabular}


Table I. Continued

\begin{tabular}{|c|c|c|c|c|c|c|}
\hline $\begin{array}{l}\text { Tested compounds } \\
\text { and extracts }\end{array}$ & $\begin{array}{l}\text { Conc., } \mu g / \\
\mathrm{mL}\end{array}$ & MN/I000 Bn cell & $\%$ Bn cell with $M N$ & MN/Bn Cell & CBPI & $\begin{array}{c}\text { Frequency of } \mathrm{MN} \\
(\%)\end{array}$ \\
\hline \multirow[t]{3}{*}{15} & 1.0 & $24.03 \pm 0.6 \mathrm{I}^{\mathrm{a}^{*}, \mathrm{c}}$ & $1.92 \pm 0.09$ & $1.20 \pm 0.03$ & $1.68 \pm 0.02$ & 89.90 \\
\hline & 2.0 & $23.43 \pm 0.67^{a, c}$ & $1,83 \pm 0.08$ & $1.24 \pm 0.05$ & $1.67 \pm 0.02$ & 87.65 \\
\hline & 4.0 & $21.56 \pm\left. 0.7\right|^{a, c}$ & $1.79 \pm 0.09$ & $1.21 \pm 0.06$ & $1.70 \pm 0.05$ & 80.66 \\
\hline \multirow[t]{3}{*}{16} & 1.0 & $21.42 \pm 0.54^{\mathrm{a}, \mathrm{c}}$ & $1.74 \pm 0.13$ & $1.29 \pm 0.07$ & $1.67 \pm 0.08$ & 75.07 \\
\hline & 2.0 & $20.97 \pm 0.85^{a, c}$ & $1.78 \pm 0.12$ & $1.24 \pm 0.08$ & $1.64 \pm 0.08$ & 73.73 \\
\hline & 4.0 & $19.76 \pm 0.93^{a, b^{*}, c}$ & $1.65 \pm 0.06$ & $1.31 \pm 0.09$ & $1.60 \pm 0.03$ & 69.52 \\
\hline \multirow{3}{*}{$\begin{array}{l}\text { Euphorbia } \\
\text { dendroides } \\
\text { extract I7 }\end{array}$} & 1.0 & $18.89 \pm 0.62^{a, b, c}$ & $1.51 \pm 0.06$ & $1.18 \pm 0.04$ & $1.67 \pm 0.02$ & 66.27 \\
\hline & 2.0 & $18.60 \pm 0.38^{a, b, c}$ & $1.58 \pm 0.09$ & $1.18 \pm 0.05$ & $1.68 \pm 0.02$ & 65.33 \\
\hline & 4.0 & $\left.|7.67 \pm| .7\right|^{\mathrm{a}, \mathrm{b}^{*}, \mathrm{c}}$ & $1.59 \pm 0.12$ & $1.14 \pm 0.03$ & $1.70 \pm 0.06$ & 62.06 \\
\hline \multirow{3}{*}{$\begin{array}{l}\text { Euphorbia } \\
\text { nicaeensis } \\
\text { extract I8 }\end{array}$} & 1.0 & $19.31 \pm 1.07^{a, b^{*}, c}$ & $1.64 \pm 0.09$ & $1.18 \pm 0.07$ & $1.56 \pm 0.02$ & 67.71 \\
\hline & 2.0 & $19.08 \pm 1.19^{a, b^{*}, c}$ & $1.68 \pm 0.09$ & $1.21 \pm 0.09$ & $1.58 \pm 0.02$ & 67.04 \\
\hline & 4.0 & $18.19 \pm 0.56^{a, b, c}$ & $1.52 \pm 0.08$ & $1.16 \pm 0.06$ & $1.60 \pm 0.02$ & 63.88 \\
\hline
\end{tabular}

Abbreviations: CBPI, cytokinesis-block proliferation index; MMC, mitomycin C.

$\mathrm{MN} / \mathrm{Bn}$ cells: incidence of micronuclei in binucleated cells.

$\%$ Bn cells with $\mathrm{MN}$ : binucleated cells with micronuclei.

$\mathrm{MN} / \mathrm{I} 000 \mathrm{Bn}$ cells: incidence of micronuclei in 1000 binucleated cells (examined for each concentration).

Frequency of $\mathrm{MN}$ : incidence of $\mathrm{MN}$ present like \% from control groups in cell cultures of human lymphocytes treated with different concentration of jatrophanes or plant extracts.

The statistical significance of difference between the data pairs was evaluated by one-way analysis of variance followed by the Tukey test. Statistical significance at $P<0.01$.

${ }^{a}$ Compared with control groups, statistically significant at $P<0.01$.

$a^{*}$ Compared with control groups, statistically significant at $P<0.05$.

${ }^{b}$ Compared with amifostine WR 2721 , statistically significant at $P<0.01$.

$b^{b^{*}}$ Compared with amifostine WR 272I, statistically significant at $P<0.05$.

'Compared with MMC, statistically significant at $P<0.01$.

${ }^{c^{*}}$ Compared with MMC, statistically significant difference $P<0.05$.

the tested jatrophanes pointed out that benzoyloxy at C-8 or C-9 (in 3, 4, and 13) is responsible for a prominent degree of both P-gp inhibition and DNA protection of human lymphocytes. On the other hand jatrophane $\mathbf{1}$, although a moderate P-gp inhibitor, manifested high protective effect in human lymphocytes. Furthermore, somewhat higher protective effect was observed when isobutanoyloxy is at C-3 (1-3), rather than propanoyloxy at the same position (4-6). Previous studies demonstrated that $\mathbf{1}$ with isobutanoyloxy at C-3 exhibited more than 2 times stronger inhibitory effect on the sensitive NCI-H460 cell line and its resistant counterpart NCI-H460/R than 6 with propanoyloxy at the same position. $^{31}$

Compounds that stabilize MT may offer therapeutic approach for the treatment of Alzheimer's disease and related tauopathies. So far, several jatrophanes exhibited MT interacting activity and induced paclitaxel-like MTs. On the other hand detection of DNA and chromosomal damage through the elevated level of $\mathrm{MN}$ using in vitro CBMN assay in peripheral blood lymphocytes may be an indication of several diseases, such as Alzheimer's and Parkinson's.

Therefore a set of jatrophanes (1-16) and extracts of lyophilized latex of 2 Euphorbia species (17 and 18) were subjected to CBMN assay in peripheral blood lymphocytes.
Jatrophanes 1-6 and 13 (in concentration of $1 \mu \mathrm{g} / \mathrm{mL}$ ), and extracts 17 and 18 (in concentration of $4 \mu \mathrm{g} / \mathrm{mL}$ ) prominently decreased $\mathrm{MN}$ frequency and manifested notable protective effect on human lymphocytes DNA. The potential of jatrophanes as MT stabilizing drugs needs further investigation.

\section{Experimental}

\section{Subjects}

Venous blood samples were withdrawn into heparinized sterile vacutainers (Becton Dickinson, Bradford, MA) from 6 healthy nonsmoking male volunteers who had not been exposed to chemicals, drugs, or other substances. A safety protocol concerning blood-borne pathogen/biohazard was taken. The volunteers consented to use their blood for the experiment. From each subject, 2 aliquots of blood, $5 \mathrm{~mL}$ each were obtained. The study complied with the code of ethics of the World Medical Association (Helsinki Declaration of 1964, as revised in 2002). The blood samples were obtained at the Medical Unit in accordance with current Health and Ethical regulations in Serbia, Law on Health Care (2005). 


\begin{tabular}{|c|c|c|c|c|c|c|c|}
\hline $1-11$ & \multicolumn{3}{|c|}{12} & \multicolumn{4}{|c|}{ 13-16 } \\
\hline Jatrophanes & $\mathrm{R}_{1}$ & $\mathrm{R}_{2}$ & $\mathrm{R}_{3}$ & $\mathrm{R}_{4}$ & $\mathrm{R}_{5}$ & $\mathrm{R}_{6}$ & $\mathrm{R}_{7}$ \\
\hline (1) Euphodendrophane $\mathrm{B}^{\mathrm{a}}$ & $\mathrm{H}$ & $\mathrm{iBu}$ & Ac & $\mathrm{iBu}$ & Ac & Nic & $\mathrm{H}$ \\
\hline (2) Euphodendrophane $\mathrm{O}$ & OAc & $\mathrm{iBu}$ & Ac & $\mathrm{iBu}$ & Ac & Nic & $\mathrm{H}$ \\
\hline (3) Euphodendrophane K & $\mathrm{H}$ & $\mathrm{iBu}$ & Ac & $\mathrm{iBu}$ & $\mathrm{Bz}$ & Nic & $\mathrm{H}$ \\
\hline (4) Euphodendrophane $\mathrm{H}$ & $\mathrm{H}$ & $\operatorname{Pr}$ & Ac & $\mathrm{iBu}$ & $\mathrm{Bz}$ & Nic & $\mathrm{H}$ \\
\hline (5) Euphodendrophane I & $\mathrm{H}$ & $\operatorname{Pr}$ & Ac & $\mathrm{iBu}$ & $\mathrm{Nic}$ & Nic & $\mathrm{H}$ \\
\hline (6) Euphodendrophane $\mathrm{A}^{2}$ & $\mathrm{H}$ & $\operatorname{Pr}$ & Ac & $\mathrm{iBu}$ & Ac & Nic & $\mathrm{H}$ \\
\hline (7) Euphodendrophane J & $\mathrm{H}$ & $\operatorname{Pr}$ & Ac & $\mathrm{iBu}$ & $\mathrm{iBu}$ & $\mathrm{Nic}$ & $\mathrm{H}$ \\
\hline (8) Euphodendrophane L & $\mathrm{H}$ & $\mathrm{iBu}$ & Ac & $\mathrm{iBu}$ & Nic & Nic & $\mathrm{H}$ \\
\hline (9) Euphodendrophane P & OAc & $\mathrm{iBu}$ & Nic & $\mathrm{iBu}$ & Ac & $\mathrm{Nic}$ & $\mathrm{H}$ \\
\hline (10) Euphodendrophane $\mathrm{C}^{2}$ & $\mathrm{H}$ & $\operatorname{Pr}$ & Ac & $\mathrm{iBu}$ & Ac & Nic & Ac \\
\hline (11) Euphodendrophane $\mathrm{N}^{2}$ & $\mathrm{H}$ & Ac & Ac & $\mathrm{iBu}$ & Ac & $\mathrm{Nic}$ & $\mathrm{H}$ \\
\hline (12) Euphodendrophane G & ONic & iVal & Ac & 1 & 1 & l & I \\
\hline (13) Euphodendrophane $S^{a}$ & OAc & Ac & iBu & Ac & $\mathrm{Bz}$ & Ac & $\mathrm{Ac}$ \\
\hline (14) Euphodendrophane $F^{a}$ & OAc & Ac & $\mathrm{iBu}$ & Ac & $\mathrm{Nic}$ & Ac & $\mathrm{Ac}$ \\
\hline (15) Euphodendrophane $Q^{2}$ & OAc & $\operatorname{Pr}$ & $\mathrm{iBu}$ & Ac & Nic & Ac & Ac \\
\hline (16) Euphodendrophane R & OAc & Ac & $\mathrm{iBu}$ & Nic & Nic & Ac & Ac \\
\hline
\end{tabular}

Figure I. Structures of the tested jatrophanes isolated from Euphorbia dendroides and Euphorbia nicaeensis.

\section{Cytokinesis-Block Micronucleus Assay}

Jatrophanes 1-16 were isolated and purified as described. ${ }^{33,34}$ Lyophilized latex $(200 \mathrm{mg}$ ) of E. dendroides and E. nicaeensis were extracted with petroleum ether $(30 \mathrm{~mL}, 3$ times) to obtain extracts of lyophilized latex $\mathbf{1 7}(170 \mathrm{mg})$ and $\mathbf{1 8}(155$ $\mathrm{mg})$. The culture lymphocytes were treated with 3 concentrations $(1,2$, and $4 \mu \mathrm{g} / \mathrm{mL})$ of jatrophanes 1-16 and latex extracts $\mathbf{1 7}$ and 18. One cell culture served as the control and, to this, jatrophane or lyophilized latex extract was not added. Amifostine WR-2721 (Marligen-Biosciences, USA) $(1 \mu \mathrm{g} /$ $\mathrm{mL})$ was used as a positive control and MMC $(0.2 \mu \mathrm{g} / \mathrm{mL}$, in phosphate buffer) as a negative control. All cultures were incubated in a thermostat at $37^{\circ} \mathrm{C}$. Treatment with 1-18 lasted 19 hours, when after all cultures were rinsed with pure medium, transferred into $5 \mathrm{~mL}$ fresh RPMI 1640 medium (RPMI 1640 Medium +GlutaMAX + 25 mM HEPES; Invitrogen-Gibco-BRL, Vienna, Austria) and incubated for additional 72 hours. The incidence of spontaneously occurring MN in control samples was scored. The further treatment of all cultures was previously described. ${ }^{20}$

\section{Statistical Analysis}

The statistical analysis was performed using Origin software package version 7.0. The statistical significance of difference between the data pairs was evaluated by one-way analysis of variance followed by the Tukey test. Statistical difference was considered significant at $P<0.01$. The index calculating is presented as the percent of change comparing different groups.

\section{Declaration of Conflicting Interests}

The author(s) declared no potential conflicts of interest with respect to the research, authorship, and/or publication of this article. 


\section{Funding}

The author(s) disclosed receipt of the following financial support for the research, authorship, and/or publication of this article: This research was financially supported by Ministry of Science and Education of the Republic of Serbia, (Project 172053).

\section{References}

1. Migliore L, Testa A, Scarpato R, Pavese N, Petrozzi L, Bonuccelli U. Spontaneous and induced aneuploidy in peripheral blood lymphocytes of patients with Alzheimer's disease. Hum Genet. 1997;101(3):299-305.

2. Petrozzi L, Lucetti C, Gambaccini G, et al. Cytogenetic analysis oxidative damage in lymphocytes of Parkinson's disease patients. Neurol Sci. 2001;22(1):83-84.

3. Fenech M, Morley AA. Measurement of micronuclei in lymphocytes. Mutat Res. 1985;147(1-2):29-36.

4. Fenech M. The cytokinesis-block micronucleus technique: a detailed description of the method and its application to genotoxicity studies in human populations. Mutat Res. 1993;285(1):35-44.

5. Fenech M. The advantages and disadvantages of the cytokinesis-block micronucleus method. Mutat Res. 1997;392(1-2):11-18.

6. Fenech M. Important variables that influence base-line micronucleus frequency in cytokinesis-blocked lymphocytes - a biomarker for DNA damage in human populations. Mutat Res. 1998;404(1-2):155-165.

7. Fenech M. The in vitro micronucleus technique. Mutat Res. 2000;455(1-2):81-95.

8. Torres-Bugarín O, Macriz Romero N, Ramos Ibarra ML, Flores-García A, Valdez Aburto P, Zavala-Cerna MG. Genotoxic effect in autoimmune diseases evaluated by the micronucleus test assay: our experience and literature review. Biomed Res Int. 2015;2015(4):1-11.

9. Rangel-López A, Paniagua-Medina ME, Urbán-Reyes M, et al. Genetic damage in patients with chronic kidney disease, peritoneal dialysis and haemodialysis: a comparative study. Mutagenesis. 2013;28(2):219-225.

10. Salimi M, Broumand B, Mozdarani H. Association of elevated frequency of micronuclei in peripheral blood lymphocytes of type 2 diabetes patients with nephropathy complications. Mutagenesis. 2016;31(6):627-633.

11. Karaman A, Aydın H, Geçkinli B, Çetinkaya A, Karaman S. DNA damage is increased in lymphocytes of patients with metabolic syndrome. Mutat Res. 2015;782:30-35.

12. Duffaud F, Orsière T, Digue L, et al. Micronucleated lymphocyte rates from head-and-neck cancer patients. Mutat Res. 1999;439(2):259-266.

13. Bonassi S, Znaor A, Ceppi M, et al. An increased micronucleus frequency in peripheral blood lymphocytes predicts the risk of cancer in humans. Carcinogenesis. 2007;28(3):625-631.

14. Huang W-Y, Cai Y-Z, Zhang Y. Natural phenolic compounds from medicinal herbs and dietary plants: potential use for cancer prevention. Nutr Cancer. 2009;62(1):1-20.
15. Aljancić I, Stanković M, Tešević V, Vujisić L, Vajs V, Milosavljević S. Protective effect on human lymphocytes of some flavonoids isolated from two Achillea species. Nat Prod Commun. 2010;5(5):729-732.

16. Vučković I, Vajs V, Stanković M, Tešević V, Milosavljević S. A new prenylated flavanonol from Seseli annuum roots showing protective effect on human lymphocytes DNA. Chem Biodivers. 2010;7(3):698-704.

17. Novaković M, Stanković M, Vučković I, et al. Diarylheptanoids from Alnus glutinosa bark and their chemoprotective effect on human lymphocytes DNA. Planta Med. 2013;79(6):499-505.

18. Novaković M, Stanković M, Vučković I, et al. Diarylheptanoids from green alder bark and their potential for DNA protection. Chem Biodivers. 2014;11(6):872-885.

19. Stanković M, Tesević V, Vajs V, Todorović N, Milosavljević S, Godevac D. Antioxidant properties of grape seed extract on human lymphocyte oxidative defence. Planta Med. 2008;74(7):730-735.

20. Gođevac D, Tesević V, Vajs V, Milosavljević S, Stanković M. Antioxidant properties of raspberry seed extracts on micronucleus distribution in peripheral blood lymphocytes. Food Chem Toxicol. 2009;47(11):2853-2859.

21. Gođevac D, Tešević V, Vajs V, Milosavljević S, Stanković M. Blackberry seed extracts and isolated polyphenolic compounds showing protective effect on human lymphocytes DNA. J Food Sci. 2011;76(7):C1039-C1043.

22. Gođevac D, Tešević V, Vajs V, et al. Chemical composition of currant seed extracts and their protective effect on human lymphocytes DNA. J Food Sci. 2012;77(7):C779-C783.

23. Lanzotti V, Barile E, Scambia G, Ferlini C. Cyparissins A and B, jatrophane diterpenes from Euphorbia cyparissias as Pgp inhibitors and cytotoxic agents against ovarian cancer cell lines. Fitoterapia. 2015;104:75-79.

24. Aiyelaagbe OO, Adesogan K, Ekundayo O, Gloer JB. Antibacterial diterpenoids from Jatropha podagrica Hook. Phytochemistry. 2007;68(19):2420-2425.

25. Bedoya LM, Márquez N, Martínez N, et al. SJ23B, a jatrophane diterpene activates classical PKCs and displays strong activity against HIV in vitro. Biochem Pharmacol. 2009;77(6):965-978.

26. Nothias-Scaglia L-F, Retailleau P, Paolini J, et al. Jatrophane diterpenes as inhibitors of Chikungunya virus replication: structure-activity relationship and discovery of a potent lead. $J$ Nat Prod. 2014;77(6):1505-1512.

27. Li J, Li H-H, Wang W-Q, Song W-B, Wang Y-P, Xuan L-J. Jatrophane diterpenoids from Euphorbia helioscopia and their lipid-lowering activities. Fitoterapia. 2018;128:102-111.

28. Hohmann J, Molnár J, Rédei D, et al. Discovery and biological evaluation of a new family of potent modulators of multidrug resistance: reversal of multidrug resistance of mouse lymphoma cells by new natural jatrophane diterpenoids isolated from Euphorbia species. J Med Chem. 2002;45(12):2425-2431.

29. Corea G, Fattorusso E, Lanzotti V, et al. Jatrophane diterpenes as P-glycoprotein inhibitors. First insights of structure-activity relationships and discovery of a new, powerful lead. $J$ Med Chem. 2003;46(15):3395-3402. 
30. Miglietta A, Gabriel L, Appendino G, Bocca C. Biological properties of jatrophane polyesters, new microtubule-interacting agents. Cancer Chemother Pharmacol. 2003;51(1):67-74.

31. Pešić M, Banković J, Aljančić IS, et al. New anti-cancer characteristics of jatrophane diterpenes from Euphorbia dendroides. Food Chem Toxicol. 2011;49(12):3165-3173.

32. Ballatore C, Brunden KR, Huryn DM, Trojanowski JQ, Lee VM-Y, Smith AB. Microtubule stabilizing agents as potential treatment for Alzheimer's disease and related neurodegenerative tauopathies. J Med Chem. 2012;55(21):8979-8996.

33. Aljancić IS, Pesić M, Milosavljević SM, et al. Isolation and biological evaluation of jatrophane diterpenoids from Euphorbia dendroides. J Nat Prod. 2011;74(7):1613-1620.
34. Jadranin M, Pešić M, Aljančić IS, et al. Jatrophane diterpenoids from the latex of Euphorbia dendroides and their anti-P-glycoprotein activity in human multi-drug resistant cancer cell lines. Phytochemistry. 2013;86(2):208-217.

35. Gođevac D, Tesević V, Vajs V, Milosavljević S, Stanković M. Antioxidant evaluation of heterocyclic compounds by cytokinesis-block micronucleus assay. Mini Rev Med Chem. 2013;13(3):431-438.

36. Anderson RF, Amarasinghe C, Fisher LJ, Mak WB, Packer JE. Reduction in free-radical-induced DNA strand breaks and base damage through fast chemical repair by flavonoids. Free Radic Res. 2000;33(1):91-103. 